\title{
PERAN AVIATION SECURITY DALAM RANGKA MENANGKAL UPAYA KEJAHATAN PENERBANGAN (STUDI PUSTAKA DI MASKAPAI PENERBANGAN)
}

\author{
Bekti Setiadi,MM.
}

\begin{abstract}
ABSTRAC
The role of Aviation Security in maintaining, observing, researching and inspecting passengers, passenger's belongings is an obligation in the field of aviation. Aviation Security in performing the work either in the airport environment or in the airline is carried out according to the expertise required by the Directorate General of Civil Aviation must have a tiered license ranging from Basic Aviation Security to Senior Aviation Security. Therefore, library studies on aviation security is expected to provide benefits to the aviation world, especially in terms of security and flight safety.
\end{abstract}

Keywords: Aviation security, and Procedures

\section{PENDAHULUAN}

Industri penerbangan yang tumbuh dengan pesat saat ini merupakan suatu kemajuan bagi bangsa dan negara, salah satu indikatornya adalah bahwa kelas ekonomi yang menikmati maskapai penerbangan tumbuh dari berbagai strata dan sudah bukan milik suatu kalangan ekonomi seperti dahulu kala. Penumpang sebagai salah satu aset penting yang menjadi perhitungan untuk pencapaian profit dari maskapai. Perlindungan terhadap penumpang yang dilakukan oleh maskapai untuk mencapai keamanan dan keselamatan dalam suatu penerbangan sangatlah perlu diperhatikan dan diutamakan, bagaimana tidak, hak penumpang setelah reservasi tiket sudah dijamin oleh maskapai sampai pada saat penumpang tersebut sampai ke tujuan.

Sebagai pengingat saja beberapa waktu tahun lalu ada kejadian penumpang Umrah Indonesia yang berasal dari Bandar Udara Juanda terbang menggunakan maskapai Royal Brunei membawa kedapatan membawa bahan peledak jenis bondet atau bom ikan serta sejumlah peluru dan senjata tajam dalam tas kopornya, Rustawi ditahan ketika maskapai Royal Brunei yang ditumpanginya transit di Bandara Brunei pada Sabtu, 2 Mei 2015. Dari kasus yang pernah menimpa penumpang Indonesia di atas terlihat disini bahwa begitu 
leluasanya penumpang membawa bahan, barang atau yang bisa menyebabkan keselamatan dan keamanan penerbangan menjadi terancam. Tanggung jawab maskapai kepada penumpang dimulai dari dari sebelum masa penerbangan (pre-flight service), pada saat penerbangan (in-flight service), dan setelah penerbangan (post-flight service). Secara umum dikenal ada empat hak dasar konsumen, yang pertama hak untuk mendapatkan keamanan (the right to safety), kedua hak untuk mendapatkan informasi hak untuk memilih (the right to be informed) dan keempat adalah hak untuk memilih (the right to choose). Penyediaan keamanan bagi maskapai penerbangan merupakan suatu hal yang mutlak, prosedur untuk menjamin keamanan dan keselamatan penumpang dibuat oleh maskapai dan dijalankan oleh petugas yang berada dilapangan. Penjagaan oleh airlines security milik maskapai merupakan petugas yang memiliki kualifikasi sesuai dengan Surat Keputusan Dirjen Perhubungan Udara (Skep/275/XI/1999) yang isinya berbunyi sertifikat kecakapan petugas penanganan pengangkutan bahan dan atau barang berbahaya dengan pesawat udara Selain itu dalam UU No.1 tahun 2009 bagian ketiga mengenai kemanan bandara pasal 334 ayat 1 yang isinya berbunyi Orang perseorangan, kendaraan, kargo, dan pos yang akan memasuki daerah keamanan terbatas wajib memiliki izin masuk daerah terbatas atau tiket pesawat udara bagi penumpang pesawat udara, dan dilakukan pemeriksaan keamanan, pasal 334 ayat 2 isinya Pemeriksaan keamanan sebagaimana dimaksud pada ayat (1) dilakukan oleh petugas yang berkompeten di bidang keamanan penerbangan. Disini terlihat bahwa aturan baku sudah ada dan mengatur mengenai hal keselamatan dan keamanan penerbangan. Dalam Pasal 335 ayat 1 ; Terhadap penumpang, personel pesawat udara, bagasi, kargo, dan pos yang akan diangkut harus dilakukan pemeriksaan dan memenuhi persyaratan keamanan penerbangan.

Sebagai gambaran untuk peran personel Penerbangan yang terkait dengan keselamatan adalah personel yang memiliki keahlian dan kompetensi yang memiliki peran seperti :

1) Personel Pesawat Udara, yaitu personel yang terkait dengan pengoperasian pesawat udara.

2) Personel Navigasi Penerbangan, yaitu personel yang terkait dengan pelaksanaan pengoperasian dan 
pemeliharaan fasilitas Navigasi

Penerbangan.

3) Personel Bandar Udara, yaitu personel yang terkait dengan pelaksanaan pengoperasian dan pemeliharaan fasilitas Bandar Udara.

Ketiga personel tersebut harus memiliki lisensi yang sah dan sertifikasi yang masih berlaku.

Titik - titik rawan dari pengoperasian penerbangan adalah

1) Air crew

Semua crew yang bekerja di dalam suatu penerbangan harus mempunyai surat ijin atau lisensi keahlian, tujuannya agar dia mengetahui barang atau hal apa saja yang harus di lakukan agar tidak terjadi hal - hal yang tidak diinginkan.

2) Gate check

Tidak semua orang dapat masuk ke dalam bandara atau terminal, karena Setiap orang yang masuk harus ada boarding pass

\section{3) Catering}

Didalam pengiriman catering ke dalam pesawat juga merupakan cela dimana terdapat terjadinya kriminal, bisa saja catering yang di berikan kepada penumpang di beri obat yang membuat penumpang sakit bahkan meningal.

4) Cargo and mail

Kiriman yang akan di muat kedalam cargo bisa saja berisi bahan berbahaya yang menyebabkan ledakan yang cukup besar.

5) Refueling

Merupakan titik rawan yang dapat terjadi kriminal, karena di dalam pengisian fuel bisa saja ada celah atau orang yang tidak bertanggung jawab memasukan berupa zat atau cairan yang dapat meledakan pesawat.

\section{6) Checked baggage}

Bagasi yang disimpan di dalam kargo, bisa saja berisi bahan-bahan berbahaya. Yang dapat menyebabkan kerusakan kepada cargo lainnya.

7) Ground staff

Ground staff yang bekerja di lapangan, antara lain cargo, teknik baik penumpang maupun staff harus juga di waspadai atau dicegah dengan suatu alat $x$-ray, WTMD (walk through metal detector), dan HHMD (hand held metal detector)

8) Passenger and carry on baggage 
a) Penumpang, awak pesawat udara dan bagasi harus diperiksa sebelum memasuki daerah steril dan sisi udara

b) Penumpang harus melapor pada Perusahaan angkutan udara

c) Nama dalam tiket harus sama dengan identitas penumpang

d) Penumpang transit dan transfer dilakukan pemeriksaan

e) Kabandara atau Adbandara dapat melakukan pemeriksaan di dalam pesawat udara

f) Batas waktu check-in 30 menit sebelum jadwal keberangkatan

g) Daerah check-in merupakan daerah terbatas yang harus dijaga petugas

Jalur yang menghubungkan daerah chek-in dengan sisi udara harus dilengkapi pintu dan dikunci saat tidak dipergunakan :

i) Pintu lalu lintas petugas harus dijaga petugas sekuriti dan dikunci apabila tidak dipergunakan
ii) Petugas
lain
turut mengawasi
dibawah

koordinasi petugas sekuriti bandara

iii) Perusahaan angkutan udara dapat menolak mengangkut penumpang yang dapat membahayakan keselamatan penerbangan

iv) Bagasi harus diperiksa sebelum diserahkan di tempat check-in (KM 14/1989 Ps. 3)

v) Bagasi harus dilengkapi identitas pemilik.

vi) Bagasi yang ditolak dengan alasan keamanan penerbangan tidak dibenarkan untuk diangkut.

vii) Senjata api, senjata tajam serta benda lain yang dapat dipakai sebagai alat untuk mengancam atau memaksakan kehendak dilarang dimasukkan atau ditempatkan di dalam kabin pesawat udara.

viii) Kargo dan kiriman pos harus

diperiksa sebelum dimasukkan ke gudang atau pesawat udara. 

i) Pemeriksaan memperhatikan
pos perlu kelancaran pengirimannya.
j) Pemeriksaan pengangkutan barang- barang berbahaya harus memperhatikan ketentuan yang berlaku.

Pengertian Pengamanan Berdasarkan Keputusan Menteri Perhubungan Nomor KM 54 tahun 2004 tanggal 21 Mei 2004 Pengamanan (security) adalah gabungan sumber daya manusia, fasilitas dan materil serta prosedur untuk melindungi penerbangan dari tindakan gangguan melawan hukum. Sedangkan upaya pengamanan (Security control) adalah upaya pencegahan terhadap penyusupan senjata, bahan peledak atau bahan - bahan lain yang mungkin digunakan untuk melakukan tindakan gangguan melawan hukum. Pada Annex 17 Definisi Security adalah, Security is a combination of measures and human and material resources intended to safeguard civil aviation against acts of unlawful interference. Personil Keamanan Penerbangan adalah personil yang telah memiliki lisensi yang diberi tugas dan tanggung jawab di bidang keamanan penerbangan. (Peraturan Direktur Jenderal
PerhubunganUdaraNomor:SKEP/2765/XII/20 10 Bab I butir 9).

Setelah penjabaran pendahuluan di atas mengenai garis besar mengenai pengamanan dalam suatu maskapai ataupun apa yang diamankan, maka akan dilanjutkan mengenai prosedur yang dilaksanakan oleh airlines security dalan melaksanakan kegiatannya.

\section{PROSEDUR}

Yang harus diikuti dalam pelaksanaan kerja untuk mendukung dan menjaga keamanan dan keselamatan penumpang adalah dengan mengikuti semua prosedur baku dan selanjutnya peran airlines security untuk memastikan keamanan dan keselamatan penumpang, pesawat, dan barang yang dimuat, terlihat disini beberapa prosedur yang telah dibuat sebagai berikut ;

Pengamanan terhadap penumpang dan bagasi check in dan baggage handling meliputi ;

1) Memastikan bahwa semua penumpang berada di area check in telah melalui SCP I yang dilakukan oleh keamanan bandara.

2) Amati karakteristik calon penumpang, laporkan kepada Supervisor, Check In dari aviation security apabila menemukan 
penumpang dengan perilaku tidak wajar seperti ;
a. Nervous atau gelisah
b. Agresif atau terlalu bersahabat
c. Pasif, menghindari tatap muka

3) Pastikan petugas check in counter melakukan pemeriksaan kelengkapan dokumen dan kesesuain dokumen (paspor, visa, dan sebagainya) pada proses check in.

4) Pastikan penumpang yang telah melewati SCP II tidak tercampur dengan penumpang lain yang belum dilakukan pemeriksaan.I

5) Pastikan petugas check in melakukan pencegahan terhadap bagasi tentengan/cabin yang tidak sesuai ukuran yang telah ditentukan airline.

7) Pastikan checked baggage/bagasi dilengkapi dengan tangiable yang tertera No. flight tujuan maupun berat bagasi.

6) Area check in counter, baggage make up arrival dan apron area harus berada dalam pengawasan dan penerangan yang cukup dan dibantu pengawasan menggunakan CCTV yang hasil rekamannya disimpan dan di back up oleh server perusahaan.

7) Lakukan pengawasan checked baggage mulai saat dari penerimaan sampai dengan dimuat di pesawat udara begitu juga sebaliknya hingga diserahkan pada penumpang dengan cara patroli untuk menghindari tindak gangguan melawan hukum.

9) Pastikan rekonsiliasi bagasi telah dilakukan sebelum bagasi dimuat kedalam pesawat udara sesuai dengan persyaratan airlines pelanggan.

10) Lakukan pencegahan terhadap unauthorized person di baggage make up area.

11) Buat laporan kegiatan/ irregularaties.

12) Simpan data laporan di posko aviation security.

Prosedur di atas adalah aturan milik maskapai yang baku untuk dilaksanakan oleh airlines security, bukan tanpa celah dari prosedur yang telah dibuat untuk memastikan bahwa pelaksanaan dapat dilaksanakan oleh petugas.

\section{Pengamanan Liquid, Aerosol \& Gel pada} Carry Baggage.

1) Memberikan penjelasan kepada penumpang perihal ketentuan limitation LAGs untuk penumpang tujuan internasional atau penumpang dengan penerbangan internasional dimana terdapat pembatasan yang diperbolehkan seperti ;

a. Tiap item maksimal $100 \mathrm{ml}$

b.LAGs ditempatkan dalam kantung transparan reseable seal, yang isinya bila 
jumlah tidak lebih dari 1 liter dengan kemasan ukuran $20 \times 20 \mathrm{~cm}$.

c. Kemasan LAGs lebih besar dan $100 \mathrm{ml}$ tidak diijinkan meskipun tidak terisi penuh.

d. Setiap penumpang hany adiperbolehkan membawa 1 kantung. Pembelian di Airport duty frre shop harus dimasukkan ke dalam kantong plastik transparan diberi segel/STEB/security stemper evident bags serta menunjukkan bukti pembelian.

e. LAGs yang terdeteksi tidak sesuai dengan ketentuan ICAO recommended practices akan disita.

f. Pengecualian terhadap obat-obatan dengan resep dokter dan makanan bayi.

2) Lakukan pengecekan dan pencegahan LAGs di pintu boarding gate terhadap semua carry on baggage penumpang dan crew sebelum memasuki pesawat untuk mencegah adanya LAGs yang tidak terdeteksi pada SCP I dan SCP II dan jika ditemukan LAGs yang tidak sesuai ketentuan akan dilakukan penyitaan.

3) Berikan hasil sitaan LAGs kepada Airlines

4) Buat laporan kegiatan/irregulaties.

5) Simpan data laporan di posko AVSEC.

Prosedur mengenai LAGs ini adalah bahan yang sangat sukar di deteksi oleh manusia atau petugas biasa tanpa adanya pemberian bekal pelatihan, peran petugas dan menjalankan prosedur yang dibuatmaka akan terhindar dari bahan-bahan LAGs yang akan terangkut ke dalam pesawat.

\section{Pengamanan Security Item}

1) Pastikan bahwa penumpang yang membawa senjata telah terdekteksi dan diketahui oleh petuga keamanan bandara.

2) Pastikan bahwa senjata telah ditangani oleh petugas keamanan bandara sebelum diterima di check in counter.

3) Petugas AVSEC menerima senjata dan petugas keamanan bandara dan sekaligus delivery order yang telah ditanda tangani oleh pemiliknya.

4) Proses pemisahan peluru dari senjata api harus dilakukan oleh penumpang/pemilik senjata dan proses skrining penumpang untuk masuk ke daerah umum terbatas telah dilakukan oleh keamanan bandar udara pastikan bahwa kondisi peluru telah dikeluarkan dari senjata pada saat proses penyerahan kepada petugas AVSEC perusahaan sebelum dimuat ke dalam SIB / SIC di dalam compartment pesawat.

5) Catat jenis jumlah dan tujuan dari security item tersebut pada saat keberangkatan maupun kedatangan.

6) Senjata harus disimpan di tempat yang tidak dapat diakses oleh orang yang tidak 
berhak, mulai dari proses penyimpanan dan / atau selama penerbangan.

7) Petugas AVSEC akan membawa dan menyerahkannya kepada loading master untuk dimuat di SIB/SIC di dalam compartment pesawat.

8) Petugas loadsheater melaporkan pada PIC tentang posisi pemuatan senjata di compartment pesawat.

9) Masukkan security item ke dalam SIB/SIC sesuai dengan aturan.

10) SIB/SIC harus diturunkan terlebih dahulu dan dimuat paling akhir.

11)Penangan security item sesuai dengan peraturan yang telah dibuat.

12)Penyerahan security item kepada penumpang dilakukan di pintu keluar kedatangan.

13) Buat laporan kegiatan/irregularities

14) Simpan data laporan di posko avsec.

Prosedur di atas mengatur dengan jelas mengenai security item untuk penumpang dan penanganannya, bentuk senjata saat ini masih berbentuk sama dan konvensional. Jaman berubah dan teknologi maju pesat bukan tidak mungkin bentuk dari senjata api ini akan muncul berbagai macam bentuk sehingga prosedur akan mengikuti.

\section{Penanganan Pesawat dan Area Kegiatan Operasional}

1) Singkirkan benda/FOD yang berpotensi membahayakan keselamatan penerbangan.

2) Cegah unauthorized person berada di area parkir pesawat pada saat kegiatan loading unloading berlangsung.

3) Lakukan body check terhadap petugas porter pastikan sesuai WO, cleaning service pastikan sesuai job card dan petugas lainnya yang berada di bawah kendali ground handling sebelum dan sesudah pelaksanaan loading unloading untuk mencegah barangbarang yang mencurigakan masuk ke dalam pesawat.

4) Lakukan pemeriksaan pada kondisi bagasi, cargo, dan pos yang akan dimuat ke dalam pesawat,

5) Pastikan semua bagasi yang akan dimuat ke dalam pesawat (originating hold baggage) telah melalui proses security screening/x-ray dengan memperhatikan stiker security checked kecuali hold bagagge yang ditemukan setelah selesai proses check in selesai dan/atau di boarding gate (bagasi sweeping atau duty free items yang tidak boleh dibawa di dalam cabin) dan tidak memerlukan stiker security checked dengan tetap memastikan keamanan bagasi tersebut disampaikan melalui telex yang 
dikirim ke seluruh rute penerbangan bagasi tersebut.

6) Awasi proses loading unloading bagasi cargo, pos, dan security item di pesawat sampai selesai kegiatan.

7) Cegah unauthorized person di area boarding gate untuk pengantar dan penjemput di area protokol yang memasuki area boarding gate menuju pesawat.

8) Lakukan pengecekan cabin sebelum boarding dan setelah penumpang disembarkasi untuk menemukan barangbarang mencurigakan yang dapat menimbulkan ancaman terhadap penerbangan sipil.

9) Serahkan temuan cabin/barang milik penumpang yang tertinggal di cabin/seat kepada lost and found.

10) Cegah orang yang tidak berkepentingan/unauthorized person yang akan memasuki pesawat dan lakukan pengechekan id/pas bandara.

11) Buat laporan kegiatan/irregularities.

12) Simpan data di posko AVSEC.

Prosedur di atas menguraikan begitu jelas mengenai tugas dilapangan untuk petugas dalam mengawasi dan menjaga terhadap ancaman atau ada upaya yang akan dilakukan terhadap pesawat.

\section{Pengamanan Pesawat Udara di Parkir}

\section{Lama}

1) Pesawat di parkir di daerah aman pada kondisi keamanan dan perlindungan maksimal di dalam wilayah operasi bandara.

2) Pastikan GSE yang berada di sekitar pesawat berada dalam area parkir sesuai ketentuan dan dalam keadaan whell cock terpasang.

3) Pastikan Safety Done telah terpasang sesuai dengan ketentuan.

4) Pastikan whell cock telah terpasang pada landing gear dan main landing gear sesuai ketentuan.

5) Pada saat pesawat tidak ada personal/petugas yang sedang bekerja, lakukan pemeriksaan terhadap kemungkinan adanya unauthorized person berada di dalam pesawat (cabin, cokpit, cargo compartment, dan pintu akses lainnya). Kemudian seluruh pintu harus ditutup (pintu penumpang dan cargo compartment) termasuk tangga kerja, tangga penumpang, aviobridge ditarik dan atau tidak terpasang di pesawat udara.

6) Pastikan setiap pesawat yang RON/di parkir lama harus mendapat penerangan yang cukup dan mendapatkan pengawasan secara kontinu dari petugas security. Apabila penerangan belum cukup memadai segera mealporkan kepada pengelola bandara. 
7) Lakukan pencegahan terhadap orang dan atau kendaraan yang tidak berkepentingan berada di area sekitar pesawat.

8) Lakukan sealing kepada aircraft cabin door apabila ada permintaan dari airlines dan pelaksanaan sealing dilakukan oleh airlines/teknik of duty.

9) Lakukan pemeriksaan interior dan exterior pesawat sebelum dilakukan proses boarding dan atau loading untuk mencari dan mencegah masuknya barang/barang berbahaya/barang mencurigakan yang dapat menimbulkan ancaman terhadap keamanan dan keselamatan pesawat udara selama di darat.

10) Buat laporan kegiatan/irregulaties.

11) Simpan data laporan di posko AVSEC.

Parkir pesawat setelah tidak ada rute bagi maskapai merupakan suatu tuntutan untuk jadwal selanjutnya untuk besok pagi dalam melanjutkan rute. Petugas dalam menjalankan pekerjaan dan telah ditetapkan harus melaksanakannya sesuai dan tanpa celah.

\section{Pengamanan Pada Saat Kondisi Ancaman Meningkat}

Koordinasi antar petugas lapangan dengan perusahaan penerbangan yang merasa terancam dari gangguan pihak-pihak yang menginginkan suatu kejahatan. Tingkatan ancaman bisa dilihat apakah ancaman bisa diatasi oleh petugas aviation security atau airlines security, atau pada keadaan kondisi merah dan kuning, dimana pada kondisi ancaman merah ini pihak maskapai, aviation security bandara dan pihak kepolisian resort atau komando rayon militer terdekat.

\section{Pelaksanaan Pengamanan di Check In dan Boarding Gate}

1) Pastikan check baggage memiliki stiker security check pada saat penerimaan berlangsung.

2) Pastikan cabin baggage yang masuk ke dalam pesawat telah diperiksa dan diberikan stiker security check.

3) Pastikan pengawasan terhadap penumpang dan cabin baggage antara check in counter area sampai dengan boarding gate area.

Petugas dalam melaksanakan dan menjalankan pengamanan terhadap penumpang dan barang harus secara mendetail dan seksama menurut prosedur yang dijabarkan di atas.

\section{Pengamanan Pax, Bagasi di Make Up Area} dan Pesawat

1) Pastikan seluruh pax telah melalui SCP I dan SCP II serta dinyatakan clear oleh petugas keamanan bandara sebelum memasuki pesawat.

2) Pastikan bagasi yang diterima dari check in counter telah memiliki stiker security check. 
3) Lakukan $x$-ray ulang pada setiap bagasi termasuk bagasi transit.

4) Pastikan setiap bagasi termasuk bagasi transit mempunyai bag tag.

5) Lakukan $x$-ray ulang bagasi yang tidak memliki stiker security check.

6) Pada saat memasukkan bagasi menuju make up area pergunakan hanya satu pintu untuk memudahkan pengawasan.

7) Bila ditemukan perbedaan perhitungan antara check list dengan total system selesaikan sebelum container atau gerobak ditarik ke pesawat. (ISAGO Bagian 13 7).

8) Pengamanan di aktivitas Ramp Area.

9) Lakukan serah terima bagasi pada security di apron sesuai total bagasi per gerobak.

10) Pastikan bagasi yang akan dimasukkan ke dalam pesawat mempunyai stiker security check.

11) Bila terdapat bagasi tidak berstiker security check kembalikan ke check in area untuk dilakukan $x$-ray ulang.

12) Pastikan setiap checked bagasi termasuk transit bagasi mempunyai bag tag.

13) Pada saat memasukkan bagasi ke pesawat lakukan satu persatu untuk memudahkan pengawasan.

14) Bila ditemukan perbedaan perhintungan antara checklist loading master dengan total bagasi di gerobak harus diselesaikan sebelum pesawat berangkat.

15) Lakukan body search kepada semua orang yang bertugas di pesawat.

16) Lakukan pre flight security check untuk $\mathrm{A} / \mathrm{C}$ ex RON.

17) Buat laporan kegiatan/irregulaties kepada airlines.

18) Simpan data laporan di posko AVSEC.

Petugas dalam melaksanakan pekerjaan perlu menyikapi satu-persatu prosedur di atas dengan seksama dan teliti untuk menghindari adanya usaha atau kesengajaan yang ingin memasukkan akan barang-barang yang dapat mengancam atau barang berbahaya bagi penerbangan.

\section{Pelaporan Terhadap Ada/Terjadinya}

\section{Tindakan Gangguan Melawan Hukum}

Pelaporan ini dilakukan oleh Manager Aviation security yang ada kepada General Manager dan diteruskan kepada maskapai dan otoritas keamanan penerbangan yang terkait. Langkah-langkahnya buat laporan kegiatan/irregularitties dan penyimpanan data laporan dan flight irregularities. Pelaporan kepada General Manager dilakukan apabila ada kejadian status kuning dan status merah yang butuh tindakan bantuan dari pihak kepolisian dan tentara untuk membantu menangani keadaan atau kondisi yang sedang 
terjadi di maskapai di stau bandara atau di bandara yang terjadi kekacauan atau tindakan emergensi lainnya.

\section{Data Rekaman Circuit Closed Television (CCTV)}

Penyimpanan data rekaman CCTV selama satu bulan.

Penggunaan teknologi dalam mendukung keamanan dan keselamatan penerbangan diterapkan dan dilaksanakan, sehingga membantu dalam melacak, merekam pelaku, atau gerak-gerik daripada barang-barang, atau petugas porter yang akan memindahkan barang dari gudang kargo menuju pesawat.

\section{KESIMPULAN}

Berdasarkan penjabaran di atas maka kesimpulan sebagai berikut ;

1. Ketelitian petugas dilapangan menentukan dalam hal keamanan dan keselamatan penerbangan.

2. Informasi kepada penumpang mengenai LAGs dirasakan kurang, walaupun pengetahuan petugas dan prosedur telah dibuat oleh otoritas bandara dan maskapai penerbangan.

3. Penumpang yang membawa dan ingin mengangkut atau membawa sejatanya yang termasuk kategori security item harus mendaftarkan kepada airlines sesuai dengan prosedur penanganan security item.
4. Jauhkan unauthorized person dari daerah apron gate ataupun yang tidak berkepentingan.

5. Koordinasi dengan otoritas bandara mengenai pesawat yang akan parkir di bandara dengan memperhatikan well cock dan safety done.

6. Koordinasi dengan pihak luar seperti Kepolisian RI dan TNI dalam membantu penanganan atau adanya tindakan ancaman yang tidak bisa ditangani oleh aviation security ataupun pihak maskapai.

\section{DAFTAR PUSTAKA}

Undang-Undang Republik Indonesia nomor 1 Tahun 2009 tentang Penerbangan. Republik Indonesia.

https://nasional.tempo.co/read/664599/kasusbondet-lolos-ke-brunei-juanda-klaim$\mathrm{x}$-ray-nya-canggih.

The Consumer American Society, Personal Family and Family Finance, Ed.5, New York, Mc.Graw Hill, Hal.23.

Prosedur Kerja Aviation Security PT. Gapura Angkasa, Bandara Soekarno-Hatta Mastra , IG.P, Firdiansyah, Ryan dan Faried, Muhammad. (2017). Keamanan dan Keselamatan Penerbangan. Jakarta: Mitra Wacana Media. 